Sari Pediatri, Vol. 2, No. 1, Juni 2000 


\title{
Bayi Terlahir Dari Ibu Pengidap Hepatitis B
}

\author{
Purnamawati S Pujiarto, Zuraida Zulkarnain, Julfina Bisanto, Hanifah Oswari
}

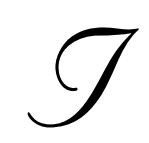
ndonesia adalah negara endemis tinggi hepatitis B dengan prevalensi HBsAg positif di populasi antara $7-10 \%$. Pada kondisi seperti ini, transmisi vertikal dari ibu ke bayi memegang peran penting. Di lain pihak, terdapat perbedaan natural history antara infeksi hepatitis B yang terjadi pada awal kehidupan dengan infeksi hepatitis $B$ yang terjadi pada masa dewasa. Infeksi yang terjadi sejak awal kehidupan atau bahkan sejak dalam kandungan, membawa risiko kronisitas sebesar $80-$ $90 \%$. Infeksi pada masa dewasa yang disebabkan oleh transmisi horisontal, mempunyai risiko kronisitas hanya sebesar $5 \%{ }^{1,2}$

Berdasarkan imunopatogenesis hepatitis $\mathrm{B}$, infeksi kronik pada anak umumnya bersifat asimtomatik. Di satu pihak, yang bersangkutan tidak menyadari bahwa dirinya sakit. Di lain pihak, individu tersebut potensial sebagai sumber penularan. ${ }^{2}$

Dalam rangka memotong transmisi infeksi hepatitis B maka kunci utama adalah imunisasi hepatitis B segera setelah lahir, secara universal, terhadap semua bayi baru lahir di Indonesia. Makalah ini akan membahas tatalaksana terhadap bayi yang lahir dari ibu mengidap/menderita hepatitis B kronik.

\section{Definisi/Batasan Operasional}

\section{Kriteria ibu mengidap atau menderita hepatitis B kronik:}

1. Bila ibu mengidap HBsAg positif untuk jangka waktu lebih dari 6 bulan dan tetap positif selama masa kehamilan dan melahirkan..$^{1,3,4}$

Staf Pengajar Subbagian Hepatologi Bagian Ilmu Kesehatan Anak FKUI-RSCM Jakarta (Dr. Purnamawati, SpA, MM(Ped), Dr. Zuraida Zulkarnain,SpA(K), Dr. Yulfina Bisanto, $S p A(K)$ dan Dr. Hanifah Oswari, SpA)

Alamat korespondensi:

Dr. Purnamawati, SpA, MM(Ped).

Jl. Salemba No. 6, Jakarta 10430, Indonesia.

Telpon: (021) 391 4126.Fax.: (021)3914126, e-mail: eji_28896@indo.net.id
2. Bila status $\mathrm{HBsAg}$ positif tidak disertai dengan peningkatan SGOT/PT maka, status ibu adalah pengidap hepatitis $B .^{1,5}$

3. Bila disertai dengan peningkatan SGOT/PT pada lebih dari 3 kali pemeriksaan dengan interval pemeriksaan a 2-3 bulan, maka status ibu adalah penderita hepatitis B kronik. ${ }^{5}$

4. Status HBsAg positif tersebut dapat disertai dengan atau tanpa $\mathrm{HBeAg}$ positif. ${ }^{1,5}$

\section{Algoritmik Tindakan}

Berikut ini adalah panduan teknis baik terhadap ibu maupun terhadap bayinya.

1. Ibu ditangani secara multidisiplin antara dokter spesialis kandungan dengan dokter spesialis penyakit dalam. Selain itu dokter spesialis kandungan juga perlu memberitahu dokter spesialis anak, Sehingga, dokter spesialis anak dapat merencanakan tatalaksana segera setelah bayi lahir. ${ }^{1-3}$

2. Pada beberapa rumah sakit di luar negeri dipertimbangkan agar kelahiran bayi melalui proses bedah kaisar. ${ }^{1,3}$

3. Satu - dua minggu sebelum taksiran partus, dokter spesialis anak memastikan tersedianya vaksin hepatitis B rekombinan dan imunoglobulin hepatitis B.

4. Pada saat ibu in partu, dokter spesialis anak mendampingi dokter spesialis kebidanan. Tindakan segera setelah bayi lahir (dalam waktu kurang dari 12 jam) adalah. ${ }^{2,6}$

a. Memberikan vaksin rekombinan hepatitis B secara IM, dosis $5 \mu \mathrm{g}$ vaksin HBVax-II atau $10 \mu \mathrm{g}$ vaksin Engerix-B.

b. Pada saat yang bersamaan, di sisi tubuh yang lain diberikan imunisasi pasif hepatitis B dalam bentuk hepatitis B imunoglobulin HBIg secara IM, dengan dosis $0.5 \mathrm{ml}$.

c. Mengingat mahalnya harga imunoglobulin hepatitis B, maka bila orang tua tidak 
mempunyai biaya, dilandaskan pada beberapa penelitian, pemberian HBIg tersebut tidak dipaksakan. Dengan catatan, imunisasi aktif hepatitis B tetap diberikan secepatnya. ${ }^{7}$

5. Tatalaksana khusus sesudah periode perinatal

a. Dilakukan pemeriksaan anti $\mathrm{HBs}$ dan $\mathrm{HBsAg}$ berkala pada usia 7 bulan (satu bulan setelah penyuntikan vaksin hepatitis B ketiga), 1, 3, 5 tahun dan selanjutnya setiap 1 tahun. ${ }^{7-9}$

(1) Bila pada usia 7 bulan tersebut anti HBs positif, dilakukan pemeriksaan ulang anti HBs dan HBsAg pada usia 1, 3, 5 dan 10 tahun. ${ }^{7-9}$

(2) Bila anti $\mathrm{HBs}$ dan $\mathrm{HBsAg}$ negatif, diberikan satu kali tambahan dosis vaksinasi dan satu bulan kemudian diulang pemeriksaan anti HBs. Bila anti HBs positif, dilakukan pemeriksaan yang sama pada usia 1, 3, dan 5 tahun, seperti pada butir a. ${ }^{8,9}$

(3) Bila pasca vaksinasi tambahan tersebut anti $\mathrm{HBs}$ dan $\mathrm{HBsAg}$ tetap negatif, bayi dinyatakan sebagai non responders dan memerlukan pemeriksaan lanjutan yang tidak akan dibahas pada makalah ini karena terlalu teknis. ${ }^{10}$

4. Bila pada usia 7 bulan anti $\mathrm{HBs}$ negatif dan $\mathrm{HBs}$ sg positif, dilakukan pemeriksaan HBsAg ulangan 6 bulan kemudian. Bila masih positif, dianggap sebagai hepatitis kronis dan dilakukan pemeriksaan SGOT/PT, USG hati, alfa feto protein, dan HBsAg, idealnya disertai dengan pemeriksaan HBV-DNA setiap 1-2 tahun. ${ }^{1,4,5}$

b. Bila HBsAg positif selama 6 bulan, dilakukan pemeriksaan SGOT/PT setiap 2-3 bulan. Bila SGOT/PT meningkat pada lebih dari 2 kali pemeriksaan dengan interval waktu 2-3 bulan, pertimbangkan terapi anti virus. ${ }^{1,4,5}$

6. Tatalaksana umum

Pemantauan tumbuh-kembang, gizi, serta pemberian imunisasi, dilakukan sebagaimana halnya dengan pemantauan terhadap bayi normal lainnya.

\section{Daftar Pustaka}

1. Koff RS. Viral Hepatitis. Dalam: Schiff L, Schiff E, penyunting. Diseases of the liver, edisi ke-7, Philadelphia: Lippincot, 1993: 492-577.

2. Balistreri W. Acute and chronic viral hepatitis. Dalam: Suchy FJ, penyunting. Liver Disease in children, edisi ke-1, St. Louis: Mosby, 1994: 460-509.

3. Zuckerman AJ, Zuckerman JN, Harrison TJ. Hepatitis B. Prevention. Dalam: Suchy FJ, penyunting. Liver Disease in children, edisi ke-1, St. Louis: Mosby, 1994: 217-29.

4. Mowat AP. Viral infections of the liver. Dalam: Mowat AP, penyunting. Liver disorders in childhood, edisi ke3. Oxford: Butterworth-Heinemann, 1994: 97-135.

5. Jacyna MR, Thomas HC. Hepatitis B. Pathogenesis and treatment of chronic infection. Dalam: Suchy FJ, penyunting. Liver Disease in children, edisi ke-1, St. Louis: Mosby, 1994: 185-207

6. American Academy of Pediatrics. Hepatitis A, B, C, and E. Dalam Peter G, Hall CB, Halsey NA, Marcey SM, Pickering LK, penyunting. 1997 Red Book. Report of the committee on infectious diseases., edisi ke-24, 1997: 237-63.

7. Poovoravan Y, Sanpavat S, Chumdermpadelsak S, Safary A. Long term hepatitis $B$ vaccine in infants born to hepatitis B e antigen positive mothers. Arch Dis Childh 1997: 77: F47-51.

8. Tang J-R, Hou H-Y, Lin H-H, Ni Y-H, Chang M-H. Hepatitis B surface antigenemia at birth. A long term follow up study. J Pediat 1998; 133 (3): 374-7.

9. Huang L-M, Chiang B-L, Lee C-Y, Lee P-I, Chi W-K, Chang $\mathrm{M}-\mathrm{H}$. Long term response to hepatitis $\mathrm{B}$ vaccine and response to booster in children born to mothers with HBeAg. Hepatology 1999; 29 (3): 954-9.

10. Carman WF, Zanetti AR, Karayiannis P, dan kawankawan. Vaccine-induced escape mutant of hepatitis B virus. Lancet 1990; 336: 325-9. 